\title{
SiM
}

\section{Summary of a National-Scale Assessment of the Ecological Site Description (ESD) Database}

\author{
By Dirac Twidwell, Brady W. Allred, and Samuel D. Fuhlendorf
}

\section{On The Ground}

- Ecological Site Descriptions (ESDs) and underlying state-and-transition models are part of a move toward a more dynamic platform of range management, but this movement is happening without evaluation of weaknesses or logical pitfalls in the ESD database.

- We conducted a national-scale evaluation of the ESD database and in this paper summarize the results with particular attention on the implementation of the state-and-transition model concept within the ESD database.

- We discuss the weaknesses and logical holes we identified and provide recommendations that can be used to organize efforts to improve, adapt, or discard certain elements of ESD state-and-transition models.

Keywords: Ecological Site Description (ESD), state-and-transition models, pitfalls, ecosystem management.

\section{Rangelands 36(4):13-17}

doi: 10.2111/Rangelands-D-14-00029.1

(C) 2014 The Society for Range Management

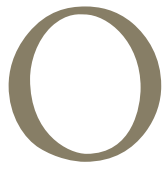

ver the last 15 years, rangeland professionals have undertaken a monumental effort to develop the Ecological Site Description (ESD) database as part of a disciplinary move toward a more dynamic platform for rangeland management. At the heart of the ESD database are state-and-transition models (Fig. 1a), which have been developed to help frame rangeland management decisions within a more dynamic context than occurred in previous rangeland assessment and management frameworks. ${ }^{1}$ After a national-level emphasis to develop these state-and-transition models, the ESD database is now being widely touted as the foundation for rangeland decision-making and is being applied in both research and management objectives across ecological disciplines (especially wildlife management). However, widespread application and promotion is occurring without a data-driven evaluation of how the state-and-transition model concept is being applied within ESDs and whether key weaknesses or logical pitfalls degrade the utility of the ESD database. We have recently conducted a national-scale evaluation of the ESD database. Our evaluation assesses the degree to which ESDs have contributed to a disciplinary shift toward a more dynamic framework for rangeland management, thereby helping managers move past preceding philosophies dominated by concepts of equilibrium, community climax, and a grazing-centric purview wherein grazing dominates rangeland dynamics and system stability. The findings from this recent evaluation were published in Twidwell et al. ${ }^{2}$ in Ecosphere.

In this article, we provide a nontechnical summary of the results of our national-scale assessment, paying particular attention to those findings associated with the implementation of the state-and-transition model concept within the ESD database. We focus on the major weaknesses and logical holes that emerged from our evaluation of ESDs to help organize efforts to improve, adapt, or entirely discard certain elements of ESD state-and-transition models during this period of revision. These focal weaknesses should also serve as critical points of consideration by users of the ESD database when developing conservation plans, implementing cost-share programs, or making rangeland management decisions. For a more thorough explanation of these findings and the methodology used to assess ESDs, readers are asked to refer to the full publication, ${ }^{2}$ which is freely available online, with open access.

\section{Summary of Major Ecological Pitfalls Within ESDs}

Grazing is overused as a driver of ecological degradation and restoration relative to other drivers of state transitions. When 


\section{(A)}

\section{Classical Range Model}

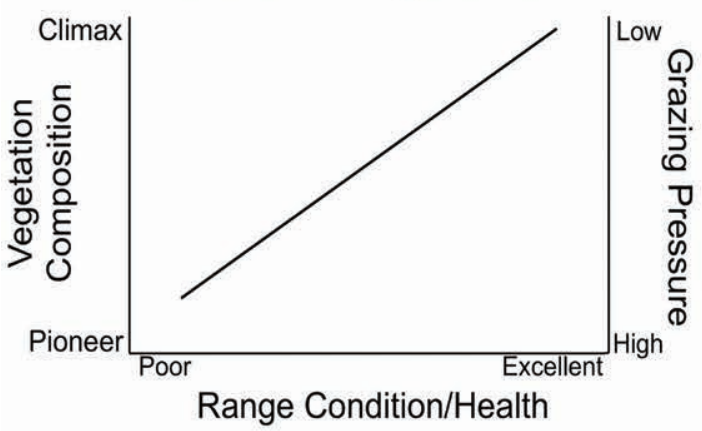

\section{State and Transition Model}

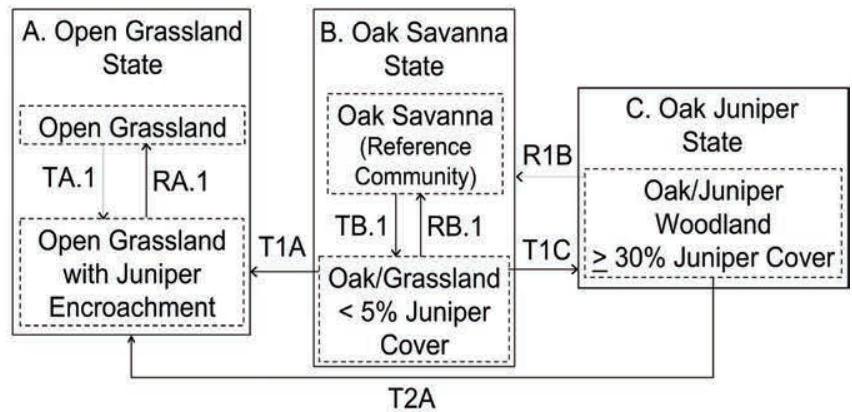

(B)

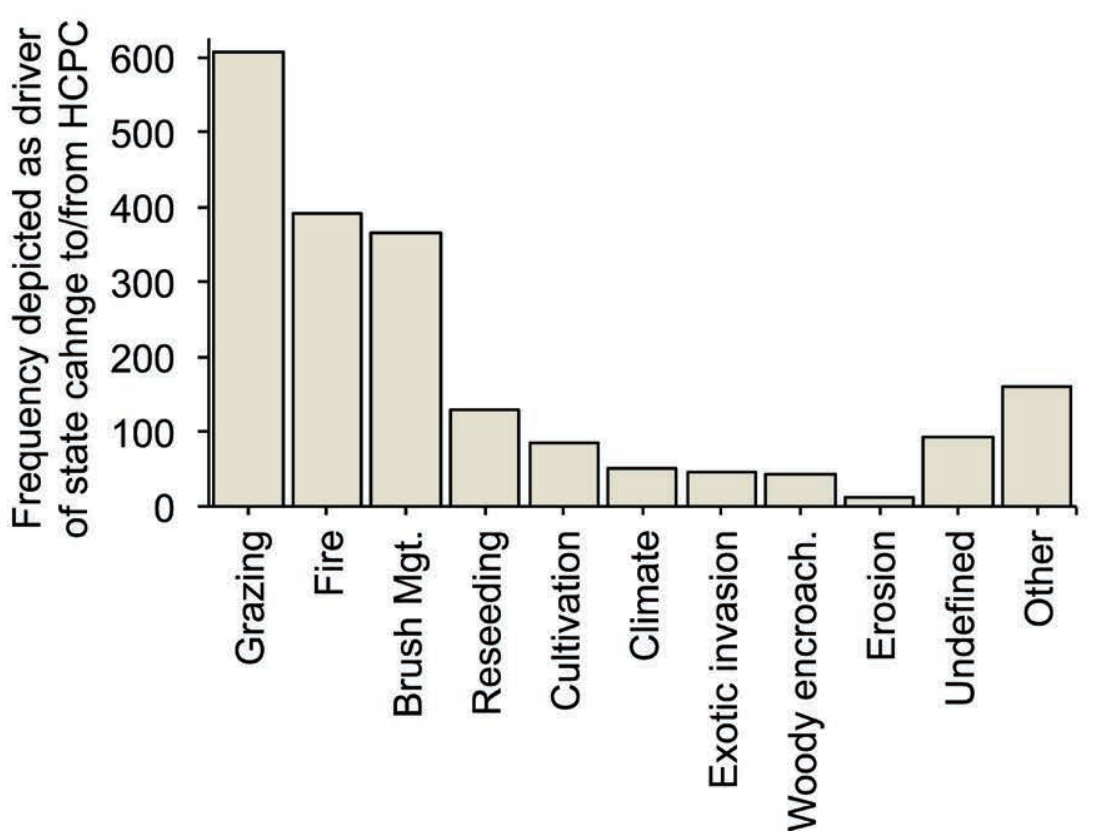

Figure 1. A, The evolution of rangeland management frameworks since 1950. The classical range model (based on Dyksterhuis ${ }^{10}$ ) proposed that vegetation composition could be maintained at a desired equilibrium by solely changing grazing pressure. The inability of the classical range model to account for various changes in rangeland vegetation and its overreliance on grazing as a driver of vegetation change contributed to the adoption of state-andtransition models as the guiding framework for rangeland management over the past 15 years. B, However, state-and-transition models continue to emphasize grazing as a driver of vegetation change considerably more than any other management action or ecological process. Overemphasizing grazing within Ecological Site Descriptions (ESDs) was shown to be a primary determinant of illogical and inaccurate portrayals of vegetation dynamics to users of the ESD database. (Figures adapted from Twidwell et al. ${ }^{2}$ )

evaluating state-and-transition models in ESDs as a collective database, grazing emerges as the clear-cut driver of both ecological degradation and restoration at a national level (Fig. 1b). This suggests that developers of ESDs consider changes in grazing to be the most important factor driving state changes in rangelands. This is occurring while the same developers characterize encroachment and reduction of woody plants as the two dominant types of state changes occurring in ESDs. This is clearly an issue because it implicates grazing as the leading factor responsible for increases or decreases in woody plant abundance at a national level, which is not supported (see Twidwell et al., ${ }^{3}$ and the chapters by Archer et al. ${ }^{4}$ and Fuhlendorf et al. ${ }^{5}$ in the Natural Resources Conservation Service (NRCS)-funded Conservation Effects Assessment Project report). ESDs are therefore more indicative of what rangeland professionals do or think, which has historically revolved around grazing, rather than representative of the actual ecological processes and management actions that cause state changes in rangelands.

Changes in grazing do not restore eroded states or exotic, invaded states to their original conditions. Multiple unrealistic expectations of ecological restoration were featured in ESDs, with the vast majority being linked to unrealistic outcomes associated with grazing. Unrealistic restoration outcomes 
Table 1. Summary of major technical flaws that emerged during our national-level evaluation of the ESD database

\begin{tabular}{|c|c|c|}
\hline $\begin{array}{l}\text { Emergent property } \\
\text { of ESDs }\end{array}$ & Reasons for concern & Considerations for improvement \\
\hline $\begin{array}{l}\text { ESDs are largely } \\
\text { qualitative, template- } \\
\text { based opinions that } \\
\text { characterize vegeta- } \\
\text { tion dynamics within } \\
\text { a state-and-transition } \\
\text { model framework. }\end{array}$ & $\begin{array}{l}\text { As a result, grazing continues to be } \\
\text { the primary driver of state transitions } \\
\text { and consistently credited with causing } \\
\text { unrealistic restoration outcomes con- } \\
\text { trary to modern ecological science. } \\
\text { - What evidence exists to support the } \\
\text { claims given in ESDs? } \\
\text { - Is the rangeland discipline going to } \\
\text { truly move toward a more dynamic } \\
\text { platform for range management, or is } \\
\text { the field trapped in the grazing-centric } \\
\text { legacy of the old range model (Fig. } \\
\text { 1)? }\end{array}$ & $\begin{array}{l}\text { - Move toward evidence-based state-and-transition } \\
\text { models that place greater priority on conclusions } \\
\text { from peer-reviewed scientific models and empiri- } \\
\text { cal data over documented observations. Both } \\
\text { preceding sets of information should be empha- } \\
\text { sized over expert opinion. } \\
\text { - Specifically identify the evidence for a transition } \\
\text { that links ecological states. } \\
\text { - If the developer does not think any evidence } \\
\text { exists, state that "Documented evidence does } \\
\text { not exist, so this transition is based on expert } \\
\text { opinion" to identify research gaps and to provide } \\
\text { opportunities for peer-evaluation and input. }\end{array}$ \\
\hline $\begin{array}{l}\text { ESDs are highly } \\
\text { subjective and prone } \\
\text { to bias. }\end{array}$ & $\begin{array}{l}\text { Are ESDs being used for perverse } \\
\text { incentives-e.g., to help acquire tax- } \\
\text { payer-based funding to support what } \\
\text { an agency does-instead of guiding } \\
\text { range management decisions through } \\
\text { accurate and objective portrayals of } \\
\text { vegetation dynamics? }\end{array}$ & $\begin{array}{l}\text { - Increase accountability of ESDs by incorporating } \\
\text { sound ecological models of state change based } \\
\text { on understanding the magnitude and flux of eco- } \\
\text { logical processes (e.g., Twidwell et al. }{ }^{3} \text { ). } \\
\text { - Increase transparency by providing evidence that } \\
\text { justifies the inclusion of management actions as } \\
\text { a driver of state change. } \\
\text { - Be adaptable to scientific advances; seek } \\
\text { increased input and assessment from external } \\
\text { agency and scientific professionals. }\end{array}$ \\
\hline $\begin{array}{l}\text { ESDs do not meet } \\
\text { the goal of being a } \\
\text { nationally consistent } \\
\text { range management } \\
\text { framework. }\end{array}$ & $\begin{array}{l}\text { Do ESDs mostly reflect developer } \\
\text { bias, potentially leading to manage- } \\
\text { ment recommendations that reflect } \\
\text { the quality of the developer rather than } \\
\text { the quality of knowledge on ecosys- } \\
\text { tem dynamics? } \\
\text { - What inconsistencies are not ac- } \\
\text { counted for in the latest guidelines for } \\
\text { ESD development? }{ }^{11,12}\end{array}$ & $\begin{array}{l}\text { Develop more clearly specified working defini- } \\
\text { tions of what constitutes a state, a transition, and } \\
\text { transitions between states } \\
\text { - Evaluate current ESDs }{ }^{11} \text { and the REISM }{ }^{12} \text { to } \\
\text { identify sources of inconsistencies. Develop } \\
\text { strategic plans for increasing consistency among } \\
\text { ESD developers. }\end{array}$ \\
\hline $\begin{array}{l}\text { ESDs do not explain } \\
\text { how a management } \\
\text { action or ecological } \\
\text { process causes a } \\
\text { type of state change. }\end{array}$ & $\begin{array}{l}\text { Drivers of state transitions are typically } \\
\text { binary classifications (e.g., prescribed } \\
\text { grazing, lack of prescribed grazing). } \\
\text { Given this classification, how is the } \\
\text { ESD database useful to rangeland } \\
\text { managers trying to implement man- } \\
\text { agement actions? What magnitude } \\
\text { of intervention is required? At what } \\
\text { return interval? } \\
\text { - How are the NRCS and the ESD } \\
\text { database accountable for unrealistic } \\
\text { portrayals of vegetation change and the } \\
\text { failed management programs that might } \\
\text { result from current ESD guidelines? }\end{array}$ & $\begin{array}{l}\text { Reconcile interactions among management } \\
\text { actions and specifically identify the relative } \\
\text { importance of each in causing state transitions. } \\
\text { Discontinue tendency to characterize a single } \\
\text { type of state change using multiple, simultane- } \\
\text { ously occurring ecological processes. } \\
\text { - Reconcile spatial and temporal scale and vari- } \\
\text { ability when characterizing the effect of a given } \\
\text { management action (e.g., Bestelmeyer et al. }{ }^{13} \text { ). } \\
\text { - Reconcile the magnitude of a management } \\
\text { action needed to cross a threshold separating } \\
\text { alternative states (e.g., Twidwell et al. }{ }^{3} \text { ). }\end{array}$ \\
\hline
\end{tabular}


occur in state-and-transition models when a nonsensical transition links a degraded state back to its original condition. For example, $49 \%$ of ESDs showed exotic species could be eradicated and returned from an exotic-dominated state back to a previous state without the exotic species. Of these ESDs, 60\% linked grazing to the eradication and reversal of an exotic-dominated state, which was more than any other management action or ecological process.

These unrealistic trends were also observed for multiple other restoration outcomes. Grazing was the number one driver linked to the restoration of an eroded state back to its original condition, and grazing was more frequently linked to state changes associated with reductions in woody plant abundance than fire and almost as often as brush management. Such grazing-induced state shifts are not supported in a recent NRCS-funded scientific evaluation of rangeland restoration practices, ${ }^{6}$ and their inclusion in ESDs warrants concern over the integration of rangeland science into management-especially given similar unrealistic claims that grazing can reverse desertification and return atmospheric carbon to preindustrial levels (see Briske et al. ${ }^{7}$ for a summary of this controversy).

ESDs are not currently suitable tools for projecting climate change impacts in rangelands. One of the main justifications for the existence of ESDs is that they can help guide rangeland management decisions in the face of new threats to rangeland resources. Some people have even suggested that ESDs have the potential to be a valuable tool for forecasting the potential impacts of climate change in rangelands (e.g., Allen et al. ${ }^{8}$ ). In their present form, however, the role of climate in driving state transitions within the ESD database is very inconsistent. ESDs typically give only the monthly and annual distributions of precipitation and temperature in order to define the spatial extent of ecological sites. Yet, few ESDs feature climate as a driver of vegetation change, and those that do often contradict the states and transitions depicted for adjacent land areas (e.g., climate is listed as an important driver of state transitions in western Oklahoma and the Texas panhandle but given minimal or no attention within ESDs in adjacent and very similar Major Land Resource Areas).

This suggests the following: 1) many ESD developers do not consider climate change to be a realistic driver of state change in the near future, 2) ESD developers focus almost exclusively on the drivers of state change that have occurred in the recent past (e.g., woody plant encroachment), and 3) ESDs are highly subjective and prone to bias, leading to widely different interpretations of how climate and other factors contribute to vegetation change in rangelands. In any case, such limitations remove the possibility to use ESDs as a forecasting framework and will require significant modifications in organization and development if ESDs are to become a nationally consistent database for understanding climate-induced vegetation change in rangelands.

\section{Considerations for ESD Development}

The process of developing ESDs continues today. Workshops are held at several ecological conferences to expose individuals to ESDs and train them in the developmental process. While some ESDs accurately reflect the current state of the science in understanding state transitions, users and developers should be cognizant of the ecological pitfalls that currently exist within the overwhelming majority of ESDs. Most importantly, the reasons for disregarding the old range model continue to persist (e.g., Fig. 1).

Many of these pitfalls can be improved. Much of the inconsistency and illogical model output is the result of a number of technical flaws that should be considered during further ESD development (Table 1). These technical flaws are explained in detail in the full paper, ${ }^{2}$ which should be consulted for additional information. We highlight these technical flaws here to demonstrate how they can lead to severe concerns among rangeland scientists, reduce utility of ESDs to rangeland managers, and weaken public trust in the mission of rangeland agencies. We then provide specific points that should be considered when revising ESDs and adopted as part of regular ESD training procedures.

Importantly, our recommendations are built upon scientific principles for ecosystem management that have been around since ESDs were first developed (e.g., Christensen et al. ${ }^{9}$ ). We use this approach to highlight the general concern among the scientific community that ecosystem management frameworks, in general, do not adequately incorporate fundamental ecological principles into management decisions. It should be understood then that the lack of scientific precepts in ecosystem management is a pervasive problem across ecological specializations-from rangeland management to fisheries management-but that the rangeland discipline has consistently been at the forefront of efforts to bridge this gap. The question is whether ESDs will continue this legacy, and adapt to criticisms and concerns, thereby pushing representatives from agencies, universities, and private landowners closer together to more effectively manage rangeland resources for the public good.

\section{References}

1. National Research Council Committee on Rangeland Classification. 1994. Rangeland health: new methods to classify, inventory, and monitor rangelands. Washington, DC, USA: National Academy Press. 180 p.

2. Twidwell, D., B. W. Allred, And S. D. Fuhlendorf. 2013. National-scale assessment of ecological content in the world's largest land management framework. Ecosphere 4:art94. Available at: http://www.esajournals.org/doi/abs/10.1890/ES13-00124.1. Accessed 1 May 2014.

3. Twidwell, D., S. D. Fuhlendorf, C. A. Taylor, Jr., and W. E. Rogers. 2013. Refining fire thresholds in coupled firevegetation models to improve management of encroaching woody plants in grassland. Journal of Applied Ecology 50:603613. 
4. Archer, S. R., K. W. Davies, T. E. Fulbright, K. C. McDaniel, B. P. Wilcox, And K. I. Predick. 2011. Brush management as a rangeland conservation strategy: a critical evaluation. In: D. D. Briske [ED.]. Conservation benefits of rangeland practices: assessment, recommendations, and knowledge gaps. Lawrence, KS, USA: Allen Press, Inc. US Department of Agriculture, Natural Resources Conservation Service. p. 105-170.

5. Fuhlendorf, S. D., R. F. Limb, D. M. Engle, and R. F. MillER. 2011. Assessment of prescribed fire as a conservation practice. In: D. D. Briske [ED.]. Conservation benefits of rangeland practices: assessment, recommendations, and knowledge gaps. Lawrence, KS, USA: Allen Press, Inc. US Department of Agriculture, Natural Resources Conservation Service. p. 75-104.

6. BRiske, D. D. 2011. Conservation benefits of rangeland practices: assessment, recommendations, and knowledge gaps. Lawrence, KS, USA: Allen Press, Inc. US Department of Agriculture, Natural Resources Conservation Service. 429 p.

7. Briske, D. D., B. T. Bestelmeyer, J. R. Brown, S. D. FuhlenDorf, ANd H. W. Polley. 2013. The Savory Method can not green deserts or reverse climate change: a response to the Allan Savory TED video. Rangelands 35:72-74.

8. Allen, C. D., C. Birkeland; F. S. Chapin III, P. M. Groffman, G. R. Guntenspergen, A. K. Knapp, A. D. McGuire, P. J. Mulholland, D. P. C. Peters, D. D. Roby, and G. SugiHARA. 2009. Thresholds of climate change in ecosystems: final report, synthesis and assessment product 4.2. Reston, VA, USA: US Geological Survey. 156 p.

9. Christensen, N. L., A. M. Bartuska, J. H. Brown, S. Carpenter, C. D’Antonio, R. Francis, J. F. Franklin, J. A. MacMahon, R. F. Noss, D. J. Parsons, C. H. Peterson, M. G.
Turner, and R. G. Woodmansee. 1996. The report of the Ecological Society of America committee on the scientific basis for ecosystem management. Ecological Applications 6:665-691.

10. Dyksterhuis, E. J. 1949. Condition and management of rangeland based on quantitative ecology. Journal of Range Management 2:104-115.

11. Caudle, D., J. DiBenedetto, M. Karl, H. Sanchez, and C. ТАLвот. 2013. Interagency ecological site handbook for rangelands. 109 p. Available at: http://directives.sc.egov.usda.gov/ OpenNonWebContent.aspx? content=33943.wba. Accessed 24 June 2013.

12. US Bureau of Land Management, US Department of Agriculture Forest Service, and Natural Resources Conservation Service. 2010. Rangeland Interagency Ecological Site Manual. First edition. Available at: http://directives. sc.egov.usda.gov/OpenNonWebContent.aspx?content=27123. wba. Accessed 1 May 2014.

13. Bestelmeyer, B. T., D. P. Goolsby, and S. R. Archer. 2011. Spatial perspectives in state-and-transition models: a missing link to land management? Journal of Applied Ecology 48:746-757.

Authors are Assistant Professor and Rangeland Ecologist, Dept of Agronomy and Horticulture, University of Nebraska-Lincoln, Lincoln, NE 68583, USA, dirac.twidwell@unl.edu (Twidwell); Assistant Professor of Rangeland Ecology, College of Forestry and Conservation, University of Montana, Missoula, MT 59812, USA (Allred); and Regents Professor, Dept of Natural Resource Ecology and Management, Oklahoma State University, Stillwater, OK 74078, USA (Fublendorf). 